\title{
KOSMOPOLITANISME DALAM MAJALAH PENGHIBOER DI AWAL ABAD KE-20
}

\author{
${ }^{1}$ Ari J. Adipurwawidjana \\ ${ }^{1}$ Universitas Padjadjaran \\ 1.
}

\begin{abstract}
Abstrak
Sejarah kesusastraan Indonesia lazim dipandang memiliki awalnya dengan terbitnya karya-karya yang diterbitkan dan dipromosikan Balai Pustaka sebagai bagian dari program otoritas kolonial Belanda dalam konteks Politik Etis. Namun, pandangan yang Balai Pustaka-sentris semacam ini mengabaikan aktivitas penulisan dan penerbitan yang dilakukan pihak swasta di berbagai kota selain Batavia. Tulisan ini bertujuan menunjukkan betapa wawasan kelas menengah terdidik di Hindia Belanda pada awal abad kedua puluh melampaui yang direfleksikan dalam karya-karya terbitan Balai Pustaka. Untuk mencapai tujuan ini, diterapkan kajian materialis kultural yang memandang teks sastra maupun non-sastra sebagai bagian dari ekonomi dan kebudayaan material. Dengan berfokus pada majalah Penghiboer, yang terbit di Palembang, akan tampak betapa warga kelas menengah Hindia-Belanda memiliki kehidupan yang kosmopolitan, yang memandang dirinya merupakan bagian dari masyarakat dunia, dan, karena itu pula, menunjukkan ambivalensi dalam menyajikan identitas nasional.

Kata kunci: Penghiboer, bacaan populer, majalah, Hindia Belanda, materialisme kultural
\end{abstract}

\begin{abstract}
Indonesian literary history is commonly viewed to have had its beginnings in the publication and promotion of works by Balai Pustaka as a part of the program of the Dutch colonial authority under the auspices of the Ethical Policy. However, such Balai Pustaka-centric perspective often ignores the writing and publications carried out by the private sector in various cities other than Batavia. This piece aims at exposing how the world view of the educated middle class in the Dutch-Indies in the early twentieth century had gone beyond what is reflected in the works published by Balai Pustaka. To achieve this objective, the cultural materialist approach is employed, which views literary and non-literary texts as apart of the economy and material culture. Focusing on the magazine Penghiboer, published in Palembang, it will be apparent how the members of the middle class in the Dutch Indies lived lives in the view that they were a part of a global society, and, therefore, also shows ambivalence in presenting national identity. Keywords: Penghiboer, popular reading, magazines, Dutch Indies, cultural materialism

\section{PENDAHULUAN}

Majalah Penghiboer pertama kali terbit pada tanggal 1 Januari 1935 oleh Penerbit Krakatau di Palembang. Yang menjadi pemimpin redaksinya adalah Tjio Peng Hong, yang dalam pengantar nomor pertama majalah tersebut mengaku sudah berpengalaman "[a]mpatbelas tahon dalem journalistiek,... tetapi anem tahon meninggalken lapangan itoe." Karena itu, ia berpesan agar pembacanya tidak terlalu banyak berharap dari munculnya majalah ini, tetapi ia menganjurkan agar pembaca "preksa isinia disatoe, dan di laen fihak saja boleh bersjoekoer sanget djika dengan terbitnja PENGHIBOER ia bisa menambahi djoemblahnja pembatjaän jang memberi faedah oentoek Toean poenja roemah tangga, teroetama boeat pergaoelan."
\end{abstract}


Demikianlah harapan yang digantungkan Tjio Peng Hong pada majalah yang "moeat roepa-roepa tjerita pendek, hikajat, ilmu pengetahoean, dan laen-laen."

Kenyataanya, memang majalah itu memuat berbagai macam materi baca, yang mencerminkan pola pikir, gaya hidup, dan haluan ideologis yang beragam pula. Dalam satu edisi itu terdapat tajuk rencana dari redaksi, cerita pendek berjudul "Rechercheur" dan "Testament yang Aneh," beberapa artikel informatif non-fiksi, dua sajak yang berjudul "Iboe" dan "Roentoenan Penghidoepan," beberapa rubrik yang memuat tulisan pendek tentang sejarah dan pengetahuan umum, dan cuplikan-cuplikan berita tentang beberapa daerah di Hindia-Belanda dan mancanegara. Dalam hal itu, majalah ini memenuhi janjinya untuk menyajikan berbagai bahan bacaan untuk pengetahuan dan hiburan. Namun, majalah ini juga, demi kelangsungan hidupnya, memuat banyak iklan, yang mencerminkan gaya hidup serta wawasan masyarakat kelas menengah di zaman itu, khususnya di kota Palembang dan wilayah sekitarnya, yaitu Sumatra Selatan (yang pada saat itu juga mencakup wilayah yang kini Provinsi Lampung).

Demikian pula halnya dengan surat kabar Hoa Po, yang diterbitkan oleh Penerbit Pek \& Co. Di Semarang pada tahun 1920an dengan pemimpin redaksi Pek Siek Koen dan Lie Sim Djwe. Walaupun terbit lebih dari satu dasawarsa sebelumnya di pulau yang berbeda, terbitan berkala yang dikelola warga keturunan Tionghoa di Hindia-Belanda ini juga serupa dengan Penghiboer dalam hal jenis materi yang disajikan, gaya penulisannya, dan bahkan tata letaknya. Selain itu, seperti juga majalah Penhiboer, majalah ini bukan saja menawarkan kisah dan informasi yang melulu berkaitan dengan warga keturunan Tionghoa. Bahkan, ada beberapa tulisan yang menunjukkan bukan saja menggambarkan kehidupan warga pribumi di Hindia-Belanda melainkan juga interkasi akrab antara warga keturunan Tionghoa dan pribumi. Dunia dan kehidupan yang digambarkan dalam berbagai tulisan yang dimuat dalam majalah ini menunjukkan betapa kelas menengah di Hindia-Belanda memiliki pola yang serupa terlepas dari latar belakang etnis dan budayanya.

Kajian-kajian yang telah dihasilkan oleh Ahmat Adam (1995), Mikihiro Moriyama (2005), dan Benedict Anderson (1991) dengan data yang komprehensif telah menunjukkan bahwa teknologi cetak dan industri penerbitan telah menjadi katalis bagi terjadinya modernisasi di berbagai wilayah di Hindia Belanda. Namun, lebih daripada itu, karya penulis-penulis tersebut juga menunjukkan implikasi bahwa adanya bahan bacaan, baik itu dalam bentuk buku atau terbitan berkala seperti majalah dan surat kabar, yang dikonsumsi bersama oleh pembaca-pembaca yang tinggal di wilayah yang berbeda, memungkinkan para pembaca tersebut memiliki wawasan dan pandangan yang serupa tentang dunia serta cakupannya. Dengan kata lain, adanya teks-teks yang diproduksi industri penerbitan, bukan saja mencerminkan dunia sebagaimana yang dibayangkan dan dipahami masyarakat yang menulis dan membaca melainkan juga turut membangun dunia tersebut.

Selain itu, sebagaimana yang diisyaratkan oleh hasil penelitian Claudine Salmon (2010) dan Doris Jedamski (2009), industri penerbitan yang dikelola oleh pihak swasta di Hindia-Belanda juga memfasilitasi dan turut membangun hubungan antara warga kelas menengah terdidik di Hindia-Belanda dan di berbagai tempat di belahan bumi yang lain. Salmon berfokus kepada teks-teks yang dihasilkan warga keturunan Tionghoa di Hindia-Belanda, dan, karena itu, menunjukkan adanya interaksi antara gagasangagasan serta gaya penulisan yang berkembang di Cina daratan dan karakteristik serta tema yang diterbitkan oleh penerbit-penerbit yang dikelola oleh warga keturunan Tionhoa di Hindia-Belanda. Namun, Jedamski menunjukkan hal yang lebih. Dalam penelitiannya ia menunjukkan bahwa penulis dan penerbit keturunan Tionghoa di 
Hindia-Belanda banyak menerjemahkan karya-karya dan menyajikan berita dari Eropa, bukan saja Belanda. Dengan demikian, para pembaca di Hindia Belanda pun mengikuti perkembangan yang terjadi di negara lain di Asia, di Eropa, dan bahkan di Amerika. Karena itu pula, dapat dipahami bahwa juga tercipta wawasan bersama di antara warga kelas menengah yang tinggal secara geografis di lokasi yang berjauhan.

Melanjutkan kajian yang dilakukan Salmon (2010) dan Jedamski (2009), Elizabeth Chandra $(2011 ; 2016)$ melakukan penelitian terhadap cerita-cerita fiksi yang dihasilkan warga keturunan Tionghoa di Hindia-Belanda. Dalam dua artikel yang ditulisnya, Chandra, sebagaimana yang sudah diungkapkan juga oleh Jedamski, menjelaskan bahwa ada dua modus penulisan dalam penerbitan karya-karya fiksi. Pertama, para penulis peranakan ini menerjemahkan baik karya kanonikal dan populer sastra Eropa maupun karya sastra modern dari daratan Cina. Chandra menyatakan bahwa beberapa genre sastra dari Eropa, terutama cerita detektif, telah menjadi ragam fiksi yang populer di daratan Cina. Hal ini pun dapat dipahami mengingat bahwa dalam tradisi Tionghoa pun sudah ada jenis karya naratif yang serupa, seperti cerita tentang Hakim Bao. Proses penerjemahan dan penyaduran sudah lebih dahulu terjadi di daratan Cina sehingga kemudian para penulis di negeri itu pun menghasilkan karya-karya orisinal dalam genre yang diadaptasi dari teks-teks Barat menjadi karya yang berciri khas Tionghoa. Karya-karya inilah yang kemudian diterjemahkan oleh para penulis peranakan Cina di Hindia-Belanda. Kemudian selanjutnya, para penulis Hindia-Tionghoa ini, sebagaimana yang terjadi di daratan Cina, menulis karya-karya orisinal mereka sendiri. Demikianlah wawasan kosmopolitan dengan didukung oleh industri penerbitan antarbangsa memfasilitasi pertukaran gagasan yang melampaui batas-batas administratif politik negara.

Namun, Chandra (2011) pun ,menunjukka bahwa wawasan kosmopolitan tersebut menciptakan problematika tersendiri. Ketika terjadi konflik antara Jepang dan Cina, terjadi perpecahan dalam cara warga keturunan Tionghoa mendefinis diri mereka. Di satu sisi, mereka mengakui afiliasi mereka dengan warga non-etnis Tionghoa, dan, karena itu, mendukung dan menghormati berkembangnya nasionalisme Indonesia pada saat itu. Di sisi lain, mereka juga menunjukkan sentimen yang mendukung nasionalisme Cina sebagai upaya mendefinisi identitas nasional mereka. Namun demikian, secara umum mereka pun tetap mengakui otoritas pemerintah Hindia Belanda dan menyadari kenyataan bahwa mereka merupakan warga negara Belanda walaupun dengan hak sipil yang tidak setara dengan warga negara keturunan Eropa. Ambivalensi dalam mendefinisi identitas nasional, yang tampak dari variasi pendirian dan pandangan yang ditunjukkan dalam majalah Penghiboer dan, lebih lagi, Hoa Po.

Adipurwawidjana (2017) bahkan menunjukkan bahwa dalam kasus penerbitan majalah Bintang Hindia yang dikelola bersama oleh Clockener Brousson dan Abdoel Rivai antara tahun 1903 dan 1907, proses penerbitannya pun menautkan dua tempat geografis yang berjauhan, yaitu Negeri Belanda dan pulau Jawa karena Abdul Rivai saat itu sedang bermukim di Belanda dan ia melakuakn penulisan dan penyuntingan dari Eropa walaupun majalahnya sendiri terbit di Hindia-Belanda. Wawasan kosmopolitan yang ditunjukkan dalam majalah tersebut, sebagaimana yang diprasarankan Adipurwawidjana (2017), memiliki implikasi pula terhadap sikap dan pandangan yang tampak pada tulisan-tulisan yang dimuat terhadap hubungan kolonial antara Belanda dan Indonesia. Walaupun pada saat itu kata "Indonesia" sudah digunakan (sebagaimana juga digunakan dalam Penghiboer dan Hoa Po), kata tersebut tidak dioperasikan sebagai konsep negara-bangsa melainkan sekadar sebagai wilayah geografis. Dalam konteks ini, diakui adanya bangsa Indonesia, yang lazim dipahami mencakup bukan saja warga pribumi melainkan juga keturunan Asia dan "Sinyo," tidak serta-merta menafikan pengakuan atas otoritas Belanda dalam konteks otoritas kenegaraan. Diakui bahwa ada 
ketimpangan sosial dan diskriminasi atas warga non-Eropa, tetapi tidak secara otomatis dipahami bahwa kemerdekaan Indonesia sebagai negara-bangsa yang berdaulat merupakan cara memperbaiki keadaan. Adipurwawidjana (2017) menyatakan bahwa ada kecenderungan tulisan-tulisan yang ada mengusulkan adanya upaya hukum dan politis dalam menciptakan keadilan sosial dalam jurisdiksi Kerajaan Belanda yang tidak membeda-bedakan latar belakang budaya dan etnis tetapi tetap mengakui keabsahan otoritas pemerintah Belanda di Indonesia.

Adipurwawidjana (2017) membandingkan kondisi warga pribumi di HindiaBelanda dengan warga pribumi di Amerika Serikat. Dalam tulisannnya, Adipurwawidjana berfokus kepada tulisan-tulisan William Apess yang, alih-alih mengusulkan kemerdekaan, ditawarkan agar konsep bangsa Amerika bukan saja mencakup warga kulit putih melainkan juga warga kulit berwarna. Sesungguhnya, kasus warga keturunan Afrika di Amerika Serikat pun menunjukkan perkembangan historis yang serupa. Setelah dikeluarkannya Proklamasi Emansipasi oleh Presidan Abraham Lincoln pada tahun 1863, ada pilihan warga keturunan Afrika menjadi warga Amerika Serikat yang hak sipilnya diakui dan dilindungi negara atau menjadi warga negara merdeka di Liberia. Dalam halnya warga pribumi di Amerika Serikat, terdapat dua pilihan pula tetapi berbentuk menjadi warga Amerika Serikat biasa atau menjadi warga reservasi yang memiliki otonomi hukum dalam wilayah jurisdiksi reservasi tersebut.

Di Hindia-Belanda, keterkaitan antara wawasan kosmopolitan dan sikap terhadap kolonialisme sudah dapat terbaca dari sejak ditulisnya surat-surat Kartini (1921) kepada Stella Zeehandelaar yang mulai ditulis pada tahun 1899. Kartini mengeluhkan betapa warga Jawa, terutama kaum perempuannya, tidak mendapatkan pengakuan dan hak sipil yang setara dengan warga Eropa di dalam jurisdiksi Hindia-Belanda. Namun, ia mengakui otoritas pemerintah Belanda, yang tampak dari pengakuannya atas Wilhelmina sebagai "putri kita." Selain itu, Kartini sejak awal menyatakan bahwa ia menginginkan agar "perempuan modern," yang menurutnya ada di Barat, juga bisa terwujud di Jawa. Tampaknya, wawasan kosmopolitan semacam inilah yang dikeluhkan oleh Bhambra (2011), yang menyatakan: "Yang tampaknya mencolok bukan saja dalam kajian sosiologis melainkan juga dalam kajian akademis yang lebih luas tentang kosmopolitanisme adalah betapa lazimnya 'menjadi kosmopolitan' (sebagai praktik) diasosiasikan dengan berada di Barat dan kosmopolitanisme (sebagai konsep) dipandang sebagai sesuatu yang merupakan bagian dari Barat" (314). Dalam kasus tulisan Kartini, tampaknya memang demikian lah adanya. Kartini, ketika berbicara kepada Zeehandelaar sebagai sesama warga dunia yang membaca bahan-bahan yang serupa (selain tentunya surat-surat mereka ke satu sama lain), menganggap lokasi dunia kosmopolitan ideal tersebut di Eropa, Ketika Kartini menyatakan bahwa ia harus menghormati keinginan dan kepentingan ayahnya, ia berbicara sebagai perempuan Jawa yang terkekang, bukan sebagai anggota warga dunia kosmopolitan.

Namun, ketika perempuan kelas menengah Hindia-Belanda sudah tiba di tahun 1920an dan 1930an, dualisme antara kehidupan kosmopolitan dan kehidupan lokal tidak lagi sedemikian gamblang keterpisahannya. Hal ini ditunjukkan dalam beberapa tulisan yang muncul di majalah Hoa Po dan Penghiboer. Selain dua majalah terebut, ada pula majalah Bintang Hindia, yang pertama kali terbit tahun 1922 oleh Penerbit De Unie di Batavia. Majalah ini menggunakan nama Bintang Hindia, sebagai penghormatan kepada Bintang Hindia yang sebelumnya dikelola Abdul Rivai dan Clockener Brousson. Sesungguhnya, Abdul Rivai masih berperan sebagai redaktur senior dalam majalah baru ini. Dalam majalah-majalah ini, kerap kali muncul tulisan-tulisan yang mengkritik diskriminasi terhadap perempuan dengan menolak penafsiran bahwa tradisi patriarkal 
kebudayaan Tionghoa atau Indonesia haruslah dihormati agar tidak menjadi keeropaeropaan dan melupakan leluhur. Dalam majalah Bintang Hindia, Anna Sjarif memiliki kolom tetap yang membahas permasalahan ini. Dengan kata lain, karena adanya akses terhadap beragam bahan bacaan dari berbagai negara di dunia, wacana kosmopolitan yang tampak dalam media massa di Hindia Belanda sangat beragam dan bahkan dapat bertloak belakang satu sama lain, bahkan dalam satu majalah yang sama sekalipun.

Kosmopolitanisme tidak hanya tampak gamblang dari tulisan-tulisan yang memang mengangkat tema modernisasi kehidupan di Hindia-Belanda dan menawarkan gagasan yang menghendaki disetarakannya bangsa Indonesia (dengan latar belakang etnis apapun) dengan bangsa-bangsa lain di dunia melainkan juga tampak secara subtil pada iklan-iklan yang muncul. Iklan-iklan ini menunjukkan barang dan jasa yang dikonsumsi oleh pembaca yang menjadi pangsa pasar majalah-majalah tersebut. Selain itu, berita-berita hiburan, terutama tentang film dan bintang Hollywood juga menunjukkan betapa wawasan dan kehidupan warga kelas menengah di HindiaBelanda yang selaras dengan tren yang berkembang secara global di dunia saat itu.

\section{METODE PENELITIAN}

Kajian dalam tulisan ini menerapkan metodologi umum materialis kultural yang memperlakukan teks sebagai artefak budaya dan produk industri. Dalam kerangka metodologis ini teks sastra sperti karya fiksi atau puisi yang diproduksi pada suatu masa di wilayah geografis dan kultural tertenttu dipandang sebagai bagian dari wacana budaya dan formasi-formasi sosial-politik yang ada, bukan sebagai wahana penyampaian kebenaran (Brannigan, 1998). Dengan demikian, dalam kerangka metodologis materialisme kultural pernyataan-pernyatan yang tersaji dalam sebuah teks - baik sastra ataupun non-sastra-tidak serta-merta diterima sebagai representasi kondisi sosialpolitik pada saat itu melainkan juga mempertimbankan pola diskursif yang menjadi kecenderungan pada kondisi di masa itu untuk memiliki gambaran atas kehidupan pada zaman historis dan wilayah geografisnya. Untuk mencapai tujuan seperti itu, teks-teks tidak dibaca sebagai entitas-entitas otonom melainkan sebagai bagian-bagian dari sebuah jejaring wacana yang berkelindan. Karena itu, pembacaan atas satu teks senantiasa dibandingkan dan disandingkan dengan teks lain yang relevan. Dalam hal ini, teks yang relevan berarti teks yang berbicara tentang topik atau isu yang sama atau terkait.

Karena itu, penelitian yang dilakukan untuk kajian yang disajikan dalam tulisan ini menempuh langkah-langkah berikut. Pertama, diidentifikasi teks-teks yang relevan yang ditemukan dalam majalah-majalah yang menjadi objek penelitian. Akses terhadap majalah-majalah ini diperoleh dari dua lokasi, yaitu Perpustakaan Nasional Republik Indonesia dan koleksi digital perpustakaan Universitas Leiden, khususnya bagian koleksi khusus. Untuk bahan-bahan yang tersedia di Perpustakaan Nasional Republik Indonesia, yang masih berbentukteks fisik, dilakukan digitalisasi untuk mempermudah analisis lebih lanjutnya. Setelah itu, dilakukan pembacaan ketat terhadap teks-teks terpilih untuk memperoleh temuan-temuan sesuai dengan tujuan penelitian.

Kajian dalam tulisan ini berfokus pada majalah Penghiboer sebagai objek penelitian. Majalah ini terbit dari tahun 1930an hingga 1940an di Palembang, khususnya nomor pertama, 1 Januari 1935. Majalah ini merupakan wakil dari terbitan berkala yang memuat teks sastra dan non-sastra yang diterbitkan oleh penerbit swasta di luar pulau Jawa. Majalah ini pun sesungguhnya harus dibedakan dari majalah lain dengan nama yang sama, yang terbit di Batavia mulai tahun 1913 oleh Penerbit Ho Ban Seng Kongsie dengan pemimpin redaksi Lauw Giok Lan. Walaupun majalah ini layak juga dijadikan teks pembanding, ada dua alasan bahan ini tidak dijadikan objek fokus 

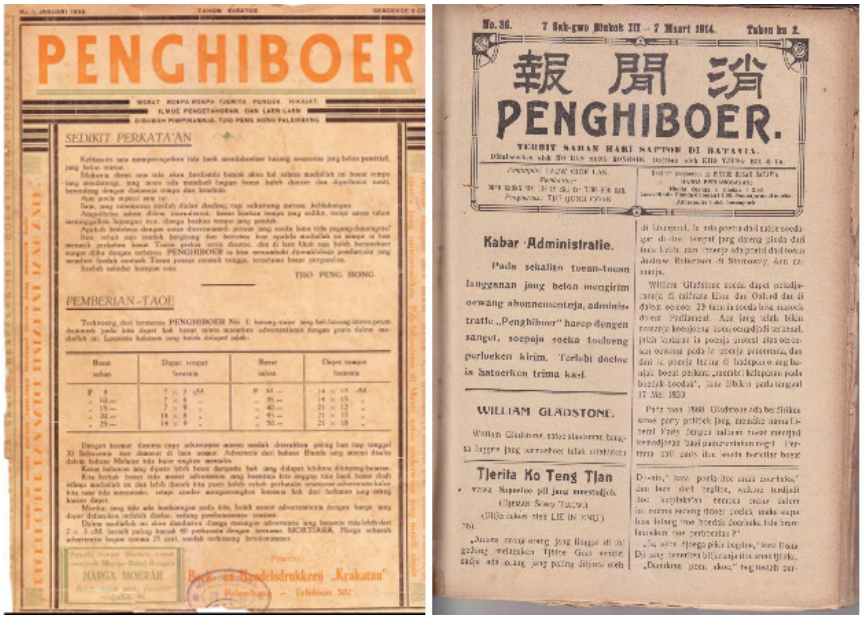

Gambar 1. Majalah

Pernghiboer terbitan

Palembang dan Semarang

utama dalam penelitian ini. Pertama, majalah ini terbit di Batavia sehingga tidak dapat mencerminkan produksi teks di luar Jawa. Kedua, kondisi fisik naskah sudah sangat rapuh sehingga perlu kajian khusus untuk meganalisis materi yang dimuat dalam majalah ini. Lagipula, konten dan struktur majalah ini tidak jauh berbeda dari bacaan populer lain yang terbit di Hindia-Belanda di awal abad kedua puluh. Namun, ada artikel menarik dalam majalah Penghiboer nomor 38 tertanggal 7 Maret 1914 tentang penggunaan bahasa di kalangan kelas menengah di Hindia-Belanda yang terkait identitas hibrid yang cenderung terbangun dalam masyrakat kosmopolitan.

Dalam melakukan analisis kajian ini membandingkan majalah Penghiboer dengan

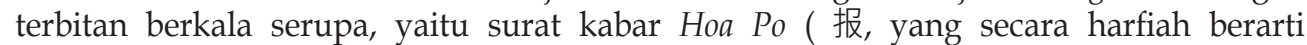
"surat kabar Tionghoa") yang terbit di tahun 1920an di Semarang. Majalah ini mewakili bacaan umum yang diterbitkan oleh pihak swasta di pulau Jawa selain di Batavia di tahun 1920an. Sesungguhnya, bahwa majalah majalah ini terbit di Semarang memiliki signifikansi penting mengingat, sebagaimana yang diutarakan Adam (1995), kota tersebut merupakan tenmpat pertama kali bahan bacaan umum dipublikasikan pihak swasta, khususnya keturunan Tionghoa di Hindia-Belanda. Hal ini disebabkan oleh adanya pasar pembaca yang tersedia di kota tersebut dengan adanya sekolah guru di sana. Walalupun seperti Penghiboer yang terbit di Palembang majalah ini didanai oleh iklan, banyaknya iklan tidak sebanyak dan tidak semendominasi tata letak majalah sebagaimana yang terjadi di Penghiboer. Dengan demikian, cerminan kehidupan dan wawasan kosmopolitan di majalah Hoa Po lebih banyak disimpulkan dari cerita fiksi dan artikel yang dimuatnya.

Selain itu, penelitian ini juga membandingkan Penghiboer materi yang dimiat di majalah Bintang Hindia yang terbit di tahun 1920an, yang berniat melanjutkan misi yang dirintis oleh majalah dengan nama yang sama yang terbit antara tahun 1903 dan 1907. Majalah ini juga dibahas karena mewakili wacana budaya yang muncul di Batavia sebagai pusat kehidupan kosmopolitan di Hindia-Belanda.

\section{HASIL DAN PEMBAHASAN}

\section{Representasi Kosmopolitanisme dalam Teks Fiksi dan Puisi}

Nomor perdana majalah Penghiboer memiliki struktur dan tata letak yang mencerminkan bentuk majalah tersebut dalam nomor-nomor selanjutnya. Dalam edisi ini dimuat dua cerita pendek. Yang pertama adalah cerita berjudul "Rechercheur" karya Tastana Jr. Medan. Dan, yang kedua adalah cerita yang berjudul "Testament yang 
Aneh: Burgemeester Maling," yang merupakan terjemahan dari karya Josef Schwadron, yang semulanya terbit pada tahun 1934 di Astra, majalah bulanan di Belanda yang berisikan bahan bacaan untuk hiburan keluarga. Masing-masing cerita ini menunjukkan wawasan dan kehidupan kosmopolitan dalam hal yang berbeda. Cerita "Rechercheur," memberikan gambaran kehidupan kosmopolitan dalam isinya sedangkan pada "Testament yang Aneh" kosmopolitanisme justru tampak pada proses penerbitannya.

"Rechercheur" berkisah tentang datangnya seseorang yang mengaku petugas kepolisian ke rumah kediaman Tuan dan Nyonya Smit. Sang "rechercheur"datang ketika Nyonya Smit berada di rumah dan melaporkan bahwa mobil Buick yang sedang pada saat itu dikendarai suaminya tercatat melintasi jalan di Krakatau-Park yang konon dilarang dilewati umum. Sang "rechecheur" pun mengabarkan bahwa Tuan Smit terlihat bersama seorang perempuan di dalam mobil tersebut. Dalam sebuah monolog interior singkat, terungkap bahwa sesungguhnya sang "rechercheur" sengaja menyertakan informasi tentang perempuan di dalam mobil tersebut untuk menciptakan kecurigaan. Tidak lama setelah itu Tuan Smit pun datang dengan mobil Buick-nya. Sang "rechercheur" menawarkan agar perkara pelanggaran tersebut diselesaikan "secara damai" dengan dirinya agar Tuan Smit terhindar dari kewajiban membayar denda dengan uang sebesar sepuluh rupiah. Ketika transaksi ilegal tersebut selesai datanglah agen polisi sesungguhnya yang kemudian menangkap yang ternayta petugas gadungan tersebut. Polisi telah alma mengintainya karena telah berulang melakukan penipuan, Di akhir cerita terungkap pula bahwa sesungguhnya perempuan yang berada di dalam mobil tersebut adalah "tante dari njonja Smit,... jang telah minta soepaja Smit anterken ia ka roemahnja dengan melintasi Krakatau-Park, itoe djalanan yang katanja terlarang."

Selintas kisah itu tampak sederhana dan biasa-biasa saja. Dan, hal itu wajar mengingat majalah Penghiboer memang merupakan majalah hiburan keluarga sebagaimana juga majalah Astra, yang penerbitan dan bentuknya diilhami oleh majalah Punch di Inggris "dengan karikatur, kartun, dan anekdot (untuk menghidupkan perbincangan di meja makan" (Koninklijke Bibliotheek, 2018). Namun bagian-bagian rinci dalam ceritanya menunjukkan dunia kosmopolitan. Pertama, tanda kosmopolitanisme yang paling gamblang adalah nama Smit, yang jelas merupakan nama keluarga Belanda walaupun latar tempat kisahnya jelas sekali di Hindia Belanda, sebagaimana tampak dari nama tempat Krakatau-Park dan penggunaan mata uang rupiah. Selain itu, disebutkannya secara ringan merk mobil Ford dan Buick menunjukkan bukan saja bahwa memiliki kendaraan bermotor beroda empat merupakan hal yang lumrah melainkan juga bahwa ada perdagangan antarbangsa yang melibatkan impor mobil dari Amerika Serikat ke Hindia Belanda.

Keberadaan Smit di Hindia Belanda dan dikisahkannya ia memiliki mobil terkait dengan menunjukkan gaya hidup yang kosmopolitan yang memiliki tingkat mobilitas yang cukup tinggi. Hal ini juga didukung oleh detail lain dalam cerita. Ketika tokoh polisi palsu menberi tahu bahwa ada perempuan bersama Smit di dalam mobil Buicknya, ia bertanya kalau-kalau perempuan itu saudara perempuan Smit atau Nyonya Smit. Nyonya Smit berkata: "Akoe poenja soedara prampoean ada di Indië." Tidak adanya komentar lain baik dari Nyonya Smit, sang "rechercheur," maupun narator cerita pendek itu menunjukkan bahwa memiliki anggota keluarga di luar negeri dianggap sesuatu yang lazim. Bukan saja itu, melainkan cara bertutur tokoh-tokohnya, terutama Tuan Smit. Secara umum, memang cerita pendek ini menggunakan bahasa Melayu Pasar yang mengandung unsur berbagai bahasa daerah, Tionghoa, dan Belanda. Namun, ada satu bagian tuturan Tuan Smit, yang, setelah setuju dengan memberi uang 
suap kepada si polisi palsu, berbunyi: "Dan boeat kira-kira brapa kaoe taksir jang akoe moesti beriken boeat ini ? Sepoeloeh roepiah ? All right. Toenggoe sebentar; akoe aken ambil oewang." Frase "All right" begitu saja tersisipkan di tengah-tengah rangkaian ujaran kalimat lain yang sepenuhnya dalam bahasa Melayu, sebagaimana juga keluarga Smit dengan wajar tersusupkan dalam lanskap Hindia Belanda.

Pada cerita pendek lain karangan Tastana Medan yang berjudul "Njai Singké," yang terbit pada Penghiboer nomor 4 tertanggal 5 Februari 1935, dikisahkan adanya pasangan, yang hidup Tan A Tjong, "satoe Tionghoa totok [yang] berasal dari salah satoe desa ketjil di Chekiang," dan Sinem, "jang menoeroet Register dari onderneming berasal dari Koethoardjo, Oost Java." Secara gamblang, narator kisah ini membandingkan pasangan miskin yang hidup "sebagi swami-istri zonder iketan perkawinan" dengan "hartawan paling besar, jang beroemah di astana mentereng, mempoejai istri yang teriket oleh perkawinan, baek diatas zegel atawa disaksiken oleh ambtenaar Burgerlijke Stand, tetapi rewel dan tida bisa akoer satoe dengan jan laen." Sinem yang memilih "ikoet sator Tjina singké jang hidoep begitoe melarat seperti koeli contract," juga dibandingkan dengan temannya Siti, yang "mendjadi njainya satoe assistent kebon di onderneming 'Mabar Estate.'" Walaupun dikisahkan pada awalnya kehidupan Siti jauh lebih nyaman daripada Sinem, selanjutnya cerita ini menyajikan kehidupan Sinem dan A Tjong membaik karena hematnya merek berumah tangga sehingga memiliki kedai sendiri dan dikaruniai anak-anak sedangkan Siti ditinggal pulang ke Belanda oleh suami Belandanya. Kisah ini menunjukkan dua hal tentang sebuah pandangan terhadap interaksi sosial antar-etnis sekaligus sikap terhadap kolonialisme Belanda di Hindia. Pertama, perkawinan antar-etnis antara Sinem dan A Tjong digambarkan sempurna karena berdasarkan cinta sehingga "tida ada satoe rintangan kerna bangsa, berlaenan tempat kelahiran, dan sebaginja." Secara eksplisit teks menyatakan kehidupan yang ideal yang melampaui batas-batas budaya dan geografi yang mewakili wawasan yang kosmopolitan dalam komteks lingkungan industri perkebunan yang pada saat itu dan hingga kini, terutama di daerah Deli, merupakan sebuah industri transnasional. Walaupun memang kehidupan kosmopolitan berlokasi di kota, kisah rural ini bagaimanapun juga dimaksudkan untuk dibaca oleh masyarakat kota, khususnya Palembang, yang seperti Medan sebagai latar tempat kisah, memiliki pelabuhan yang penting bagi perdagangan internasional. Namun, kisah ini juga menunjukkan bahwa interaksi personal dan sosial antara etnis Jawa dan Tionghoa di lingkungan Deli, Sumatera Utara yang diidealkan di sini berbeda dari interaksi antara etnis Jawa dan etnis Belanda, sebagai perwakilan dari kekuasaan kolonial yang dipandang merugikan warga setempat. Sedemikian buruknya tokoh Belanda dalam kisah ini (berbeda dari cerita Tastana Medan yang sebelumnya dibahas) sehingga dikisahkan tokoh Siti berkata kepada Sinem: "'Pancen bener kowé, Nem; jen akoe weroe nakal mengéngé, akoe ora gelem méloe londo...' (sesoenggoehnya benar kaoe Sinem, klaoe akoe taoe bakal begini, akoe tida maoe ikoet Blanda." Tampak jelas sekali bahwa kosmopolitanisme yang didukung oleh kisah ini adalah yang melibatkan interaksi antar-bangsa Asia sedangkan interaksi dengan bangsa Eropa, khususnya Belanda, dikisahkan menyebabkan penderitaan. Dengan demikian, tanpak bahwa sikap dan pandangan tentang identitas etnis dan budaya dalam masyarakat kosmpolitan di Hindia Belanda pada saait itu amat bersifat cair mengingat bahwa penulis yang sama pun dapat menghasilkan tulisan sikapnya terhadap kehadiran Belanda di Hindia sangat berbeda.

Cerita pendek lain yang dimuat dalam Penghiboer nomor perdana itu adalah "Testament yang Aneh." Teksnya sendiri merupakan terjemahan yang dilakukan 
oleh penerjemah yang tidak teridentifikasi dari sebuah cerita pendek yang terbit di Belanda di majalah Astra pada tahun 1934. Secara umum konten kisahnya sendiri tidak terlalu istimewa. Dalam cerita itu dikisahkan bahwa menjelang akhir hayatnya seorang pemimpin sebuah kota bernama Ublana (yaitu Ljubljana, inokota Slovenia) mengisahkan bahwa ia berasal dari latar belakang yang kurang terhormat, tetapi jalan hidupnya sedemikian rupa sehingga menjadi tokoh masyarakat. Teknik pengisahan yang bagaikan memoar fiktif dengan teknik naratif in medias res yang dilanjutkan dengan narasi analeptik bukanlah hal yang istimewa. Namun, hadirnya cerita pendek terjemahan kurang dari setahun dari penerbitan aslinya menunjukkan bahwa arus informasi antara Belanda dan Hindia cukup lancar. Lebih daripada itu, tidak pula mustahil bahwa majalah itu, walaupun diterbitkan di Belanda, juga beredar di Hindia. Dengan demikian, hal tersebut mencerminkan betapa kosmopolyannya industri penerbitannya sendiri, yang memiliki akses kepada bahan-bahan dari manca negaradan dianggap relevan dengan minat dan selera pasar pembacanya. Bahwa cerita pendek ini dipilih oleh redaksi untuk dimuat di nomor perdana majalahnya juga menunjukkan bahwa pembaca dianggap sudah terbiasa membaca kisah tentang peristiwa dan kehidupan di negara-negara lain.

Sebagaimana dua cerita pendek tadi, dua sajak yang dimuat dalam edisi perdana Penghiboer pun menunjukkan tanda-tanda wawasan yang kosmopolitan. Sajak "Roentoenan Penghidoepan" karya Tjio Tek Djin dan "Iboe" karya Lam Yang Djin sebagai karya sastra tidaklah terlalu istimewa. Gagasan tematik yang tersaji sesungguhnya dapatlah dikatakan klise. Yang pertama berbicara tentang liku-liku perjalanan hidup manusia yang tidak dapat dikeindalikan oleh manusia itu sendiri, yang selalu berakhir dengan kematian. Yang kedua berbicara tentang betapa berartinya sosok ibu bagi si aku liris dan kehilangan sosok itu sangat berdampak terhadap dirinya. Strukturnya pun dapat dikatakan lazim. Kedua sajak itu menggunakan bangun bait-bait berlarik empat, yang masing-masingnya berpola rima a-a-a-a, sebagaimana lumrahnya balada atau rubaiyat. Namun justru sifat biasa kedua sajak ini membuatnya menjadi perwakilan estetika populer yang sedang berlaku pada saat itu. Walaupun kedua sajak tersebut ditulis oleh penyair yang berlatar belakan etnis Tionghoa, kebudayaan yang ditunjukkan karya-karyanya menunjukkan kebudayaan modern populer yang dirintis sejak Renaisans di Eropa.

\section{Representasi Kosmopolitanisme dalam Artikel Non-Fiksi}

Selain cerita pendek, majalah Penghiboer nomor perdana ini memuat juga beberapa artikel non-fiksi yang menyajikan informasi historis. Yang pertama berjudul "Roeboehnya Keradjaän Lombok,"yang isinya sudah gamblang tercermin dari judulnya. Yang menarik dari artikel ini adalah sikap yang ditunjukkan terhadap peristiwa sejarah itu serta juga sumber yang dijadikan acuannya. Secara umum, artikel ini menyajikan peristiwa ditaklukkannya Kerajaan Lombok oleh Belanda sebagai "permoelahan dari tempo iang machmoer boeat negri dan rahajat, koetika pamerentaän radja dihapoesken dan itoe poelo dengan langsoeng ditaro dibawah pamerentaän Blanda." Peryataan tentang jatuhnya Lombok pada 27 Agustus 1894 (yang tidak lama sebelum penerbitan artikel tersebut diperingati di bulan Agustus dan September 1934) menunjukkan dukungan terhadap penaklukan tersebut sebagai peralihan masyarakat dari sistem pemerintahan feodal ke sistem modern. Namun, ada kesan juga bahwa dipandangnya penaklukan Lombok sebagai "sala-satoe bagian paling djelek dari hikajat peprangan di Indonesia" itu karena sikap terlalu mudah menyerahnya raja Lombok pada saat itu, tidak seperti peristiwa puputan di Bali yang terjadi di Bali pada 
beberapa peristiwa upaya penaklukan Bali oleh Belanda. Dengan demikian, artikel ini menunjukan sikap yang agak ambivalen, yaitu mendukung peralihan sebuah masyarakat di Indonesia ke sistem modern tetapi juga sekaligus mengagumi upaya resistensi yang heroik terhadap agresi militer Belanda. Hal ini menunjukkan betapa kompleksnya posisi warga non-Eropa di Hindia Belanda sebagai anggota masyarakat yang kosmopolitan. Di satu sisi, warga non-Eropa Hindia Belanda mengakui kebaikan kehidupan modern yang dibawa ke Hindia Belanda melalui kolonisasi Belanda sehingga menunjukkan sikap mengakui bahwa mereka merupakan bagian dari masyarakat Hindia Belanda, tetapi, di sisi lain, juga pada saat lain, mendefinisi diri dan lingkungan tempat tinggalnya sebagai Indonesia, yang berbeda dari Belanda.

Hal lain yang perlu dicatat sehubungan dengan artikel ini adalah sumbernya. Tulisan tersebut secara eksplisit menyatakan di paragraf pertamanya bahwa informasi yang disajikan berasal dari surat kabar Sin Po (新报, yang artinya “surat kabar baru”), yang merupakan publikasi yang cukup prestisius di Hindia Belanda yang sudah terbit sejak 1910. Sebagaimana yang digambarkan oleh Sudibyo (2001), surat kabar ini penting bagi masyarakat Hindia Belanda, terutama yang progresif, karena harian inilah yang pertama kali menerbitkan teks lagu Indonesia Raya. Selain itu, ia juga berperan dalam memopulerkan kata "Indonesia" sebagai pengganti istilah "Hindia Belanda." Dengan demikian, tampak bahwa Sin Po mendukung kebangkitan nasionalisme Indonesia di Hindia Belanda. Namun, pada saat yang sama, Sudibyo juga mengatakan bahwa Sin Po juga sangat kuat pendiriannya dalam mendukung nasionalisme di daratan Cina. Karena itu, tidak mengherankan jika Penghiboer, yang juga menunjukkan dualisme dalam sensibilitas nasionalnya, mengambil bahan dari Sin Po untuk isinya.

Selain itu, ada artikel yang berjudul "Asal Oesoelnja Pendoedoek Polynesie," "Bahaja Djoedi," "Berapa prempoean Amerika hamboerkan oewang boeat poeper, garen, gintjoe, lotion dan lain-lain," dan "Hikajat Orang Besar: Penghidoepanja almarhoem Radja Alexander dari Yoego-Slavië." Semua artikel di atas menyajikan isu-isu yang menjadi pembicaraan di tingkat global. Dengan menyajikan informasi tentang dugaan bahwa "pendoedoek kepoelo'an Polynesie ada toeroenan bangsa Mesir," dengan dasar bahwa "ada symbool-symbool jang bisa diliat dari itoe tiga batok boeah kelapa jang dianggep sebagi pesaka-poesaka soetji oleh bangsa Marquesa," tampak bahwa ada asumsi bahwa khalayak pembaca Penghiboer memiliki minat dalam mengetahui sejarah dunia sebagaimana juga ada pemahaman bahwa sejarah kerajaan Lombok juga merupakan perkara yang menjadi kepentingan publik pangsa pasarnya. Demikian pula, penyajian biografi Raja Alexander dari Yugoslavia, yang tidak secara langsung berkaitan dengan politik di Hindia Belanda, dianggap infomasi yang sedemikian dianggap menarik oleh calon pembaca Penghiboer sehingga dimuat dalam nomor perdananya, yang tentunya diusahakan memiliki daya tarik supaya "menambahi djoemblahnja pembatjaän," sebagaimana yang dinyatakan Tjio Peng Hong dalam pengantarnya sebagai pemimpin redaksi. Bahkan, dua artikel lain tentang judi dan konsumerisme, yang jelas disertakan dalam edisi pertama majalah itupun karena merupakan permasalahan sosial yang relevan bagi kalangan, pun berbicara tentang kondisi di negara-negara lain. Artikel itu membandingkan permasalahan judi dan cara pemerintah menindak pelanggarannya dengan membandingkan antara penanganan masalah sosial seperti "berjoedi dan madat" di Hindia Belanda - baik di Palembang, Surabaya maupun Batavia-dan di Tiongkok, yang saat itu "moelai tembak mati toekang-toekang smokkel madat" sedangkan di Hindia Belanda malah "boeat madat dan djoedi bisa dikasi licentie." Sementara itu, artikel tentang betapa eksesifnya dana yang diputar dalam industri kosmetika di 
Amerika Serikat, walaupun sepenuhnya berbicara tentang konteks di Amerika Serikat, jelas sekali bahwa yang diisyaratkan adalah bahwa kecenderungan tersebut akan atau sudah terjadi di Hindia Belanda pada saat itu. Artikel tersebut menunjukkan keresahan bahwa bahaya konsumerisme, jika sudah terbukti terjadi di Amerika Serikat, sudah pasti akan menjalar ke Hindia Belanda karena dunia mereka adalah dunia yang terglobalisasi, yang ekonominya berkelindan. Dalam masyarakat kosmopolitan batas negara dan jarak geografis tidak memisahkan kehidupan berbagai kelompok masyarakat karena mereka disatukan oleh ekonomi global dan, karena itu, persamaan kelas sosial.

Hal lain yang menunjukkan betapa artikel-artikel dalam Penghiboer mencerminkan wawasan dan kehidupan yang kosmopolitan adalah bahan-bahan yang disitasi sebagai sumber rujukan. Artikel yang membahas adanya inskripsi di Pulau Paskah (Polinesia) yang tampak terkait dengan hieroglif yang tertera di piramida di Mesir mengaku menyampaikan informasi tersebut berdasarkan otoritas "achli-achli hikajat dan wetenschap" serta "keterangan orang-orang berilmoe." Werner Wolff (1949), misalnya, menjelaskan dasar-dasar ilmiah dan bukti-bukti empiris yang mengisyaratkan adanya hubungan antara kebudayaan di Pulau Paskah dan peradabab Mesir kuno. Wolff ini, menurut Fischer (1997), merupakan salah satu tokoh yang mengembangan teori tersebut dan telah memulai penelitiannya yang menjadi sohor pada tahun 1934. Dapat diinferensi bahwa teori tersebut sedang menjadi bagian penting dalam wacana populer pada saat itu. Maka, jelas pula bahwa penulis artikel (yang menggunakan nama pena Matahari) dan penerbit Penghiboer memiliki akses terhadap bacaan-bacaan di luar Hindia Belanda. Demikian pula artikel lainnya. Tulisan "Bahaja Djoedi" secara eksplisit merujuk kepada De Indische Courant, yang terbit di Batavia, danjuga Sin Po, sehingga dapat menyajikan informasi tentang regulasi penggunaan opium di Tiongkok. Sementara itu, Artikel tentang konsumerisme yang terkait dengan industri kosmetika banyak merujuk kepada keterangan dan iklan yang dimuat di Saturday Evening Post, yang terbit di Indianapolis, Amerika Serikat. Sementara itu, artikel tentang raja Alexander dari Yugoslavia dimuat karena baru saja menjadi sasaran pembunuhan politik, "seperti jang telah dikabarken." Tampak di sini bahwa artikel itu disajikan karena memang merupakan peristiwa politik yang pada waktu itu sedang menjadi berita utama dalam wacana publik di seluruh dunia.

Demikian pula rubrik-rubrik yang memuat tulisan-tulisan anekdotal seperti "Tjontrengan," "Boeat Tertawa," "Kotak Pengalaman," dan "Taoekah Toean jang." Tulisan-tulisan yang dikumpulkan dalam rubrik-rubrik tersebut, walaupun disajikan dalam raham bahasa percakapan sehari-hari, memberikan gambaran kritis tentang situasi masyarakat Hindia Belanda pada saat itu. Dan, dalam melakukan hal tersebut, tulisan-tulisan tersebut senantiasa membandingkan kondisi lokal dengan keadaan masyarakat dan peristiwa dan peristiwa yang terjadi di negara-negara lain. Dengan demikian, tampak bahwa pola kehidupan dalam negeri dianggap sebagai bagian dari sebuah pola yang berlaku secara global.

Bahan-bahan yang menjadi rujukan tulisan-tulisan yang dimuat dalam Penghiboer juga mencerminkan kecenderungan memilih acuan yang dikenal kritis terhadap otoritas kolonial Belanda. Hal ini lebih jauh menunjukkan bahwa suara yang tampil dalam Penghiboer lebih banyak menunjukkan afiliasi ideologis kepada sesama kelas menengah di berbagai belahan dunia daripada kepada pemerintah setempat. Namun, tidak pula suara tersebut sekadar membeo tren yang sedang terjadi secara global, sebagaimana yang tampak pada artikel tentang penghamburan dana untuk industri kosmetik. Sikap kritikdiri semacam itu sesungguhnya sudah pula tampak pada terbitan berkala pendahulunya, yaitu Penghiboer, yang sudah terbit di Batavia kurang lebih dua dasawarsa sebelumnya. 
Sebagai contoh penting teks yang bersifat kritik-diri itu adalah artikel yang dimuat pada Nomor 36 tertanggal 7 Maret 1914, yang berjudul sederhana "Berbagi pamandangan." Artikel tersebut mengeluhkan betapa sudah ada kebiasaan di kalangan masyarakat kosmpoitan di Hindia Belanda. Ada "Indo Olanda jang bitjara saparo Olanda dan saparo Melajoe;" dan ada pula di kalangan kaum peranakan Tionghoa yang "ngomong Tionghoa boekan dan mengomong Melajoe poen boekan." Dengan demikian, bukan saja tulisantulisan dimuat dalam majalah dan surat kabar ini merepresntasi wawasan dan kehidupan kosmoplitan, dengan menunjukkan kemampuan mengkritiknya, suara-suara tersebut jelas sadar bahwa kosmopolitanisme merupakan ciri signifikan dalam kebudayaan mereka.

\section{Representasi Kosmopolitanisme dalam Iklan}

Pada halaman judul majalah Penhiboer, baik dalam edisi perdananya maupun dalam nomor-nomor selanjutnya, setelah tajuk rencana yang disampaikan pemimpin redaksi, tertera sebuah "Pemberian-Taoe," yang menyatakan "barang-siapa jang membeli barang atawa pesan drukwerk pada kita dapet hak boeat kita moeatken advertentienja dengan gratis dalem madjallah ini." Keterangan tersebut dilengkapi dengan syarat-syarat formatnya.

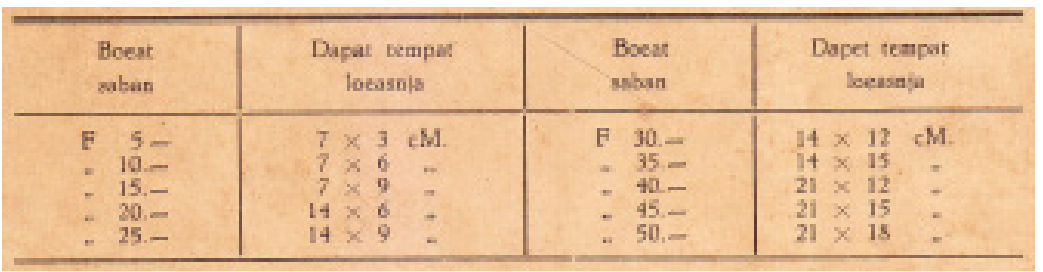

Gambar 2.

Ketentuan ukuran iklan dalam Penghiboer

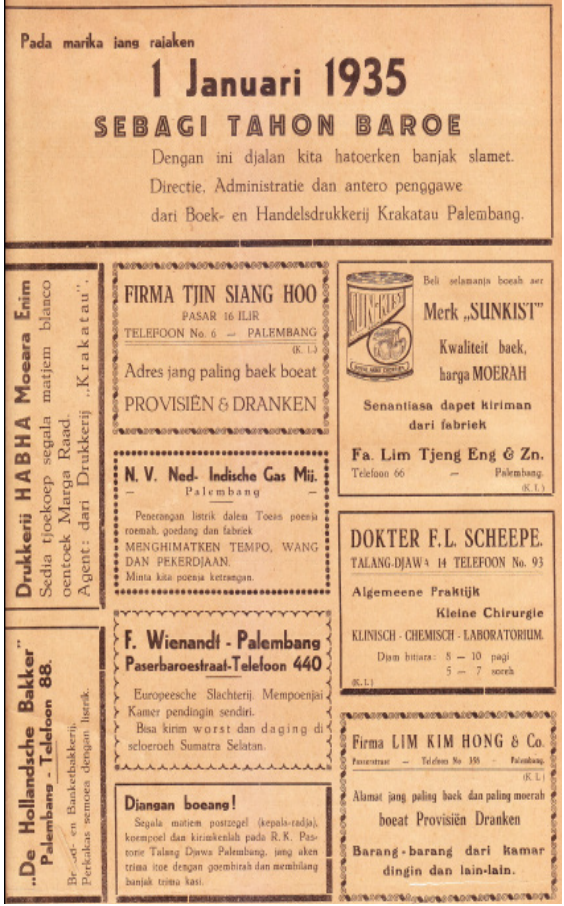

Gambar 3. Halaman kedua

Penghiboer 1 Januari 1935
Memang, sesungguhnya, tidak seperti surat kabar yang lahir di tahun 1910an, seperti Penghiboer yang terbit di Batavia atau Sin Po, Penghiboer yang terbit di Palembang sejak 1935 itu selalu menampilkan iklan di semua halamannya, dan bahkan di halaman kedua, satu halaman sepenuhnya didedikasikan untuk pemuatan iklan.

Seluruhnya ada 115 buah iklan dalam nomor perdana Penghiboer untuk berbagai produk barang dan jasa.

Iklan-iklan tersebut merepresentasi wawasan dan kehidupan kosmopolitan dengan cara yang berbeda dari karya sastra dan artikel non-fiksi. Iklan-iklan tersebut menunjukkan kosmopolitanisme, pertama, dalam hal jenis barang atau jasa yang ditawarkan. Tidak jarang beberapa iklan menawarkan produk yang diimpor dari luar negeri sebagai komoditas yang lazim dikonsumsi oleh masyarakat kelas menengah pada saar itu. Iklan yang paling banyak adalah yang menawarkan berbagai jasa dari mendistribusi hasil bumi dan produk usaha pihak lain, pengurusan administrasi dan pajak, layanan pencarian pekerjaan, dan ekspor- 


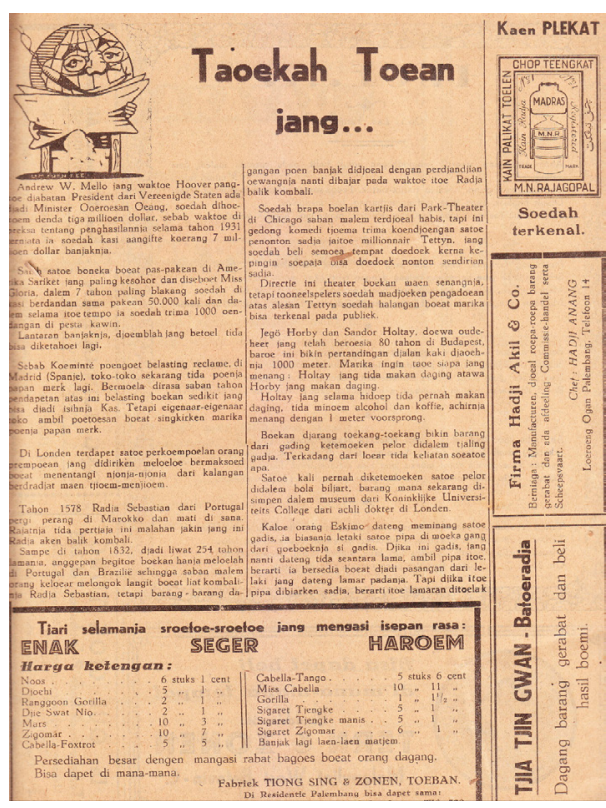

Gambar 4. Iklan yang mendominasi lembaran Penghiboer impor, sebanyak 22 buah iklan. Komoditas yang paling banyak diiklankan dalam Penghiboer edisi pertama adalah pakaian dan produk fesyen, termasuk kopiah, sebanyak 19 buah iklan. Selain itu, ada 12 iklan untuk alat-alat keperluan rumah.

Jika dibandingkan dengan iklan-iklan yang ada dalam terbitan berkala serupa di berbagai negara, akan tampak sekali bahwa gaya hidup dan pola konsumsi masyarakat kelas menengah di kotakota di Hindia Belanda tidak berbeda dari oenduduk dengan kelas sosial yang sama di negara-negara lain. Hal ini dapat dilihat dari adanya tujuh buah iklan untuk produk otomotif. Banyak pula iklan yang menunjukkan tingkat ekonomi yang baik seperti iklan bioskop, dua buah iklan bank, perhiasan dan hobi, produk tembakau, kopi, dan minuman kaleng atau botol. Banayaknya juga iklan industri perhotelan, hiburan, dan transportasi emnunjukkan

adanya waktu luang dan mobilitas tinggi yang menjadi ciri utama masyarakat kelas menengah kosmopolitan. Demikian pula, kerapnya kemunculan iklan layanan kesehatan, produk medis, dan komoditas sanitasi menunjukkan tingginya perhatian masyarakat pangsa pasar Penghiboer terhadap kesehatan dan kebersihan.

Kedua, iklan-iklan tersebut dipasang oleh produsen atau distributer yang berasal dari pihak-pihak yang memiliki latar belakang yang bervariasi. Iklan-iklan yang muncul di majalah Penghiboer memang banyak didominasi oleh usaha-usaha yang berkedudukan di kota Palembang dan kota-kota di sekitarnya seperti Lahat, Baturaja, dan Tanjungkarang. Namun, tampak dari namanya, ada yang berasal dari latar belakang budaya Melayu, Arab, India, Tionghoa, Jepang, dan Eropa.

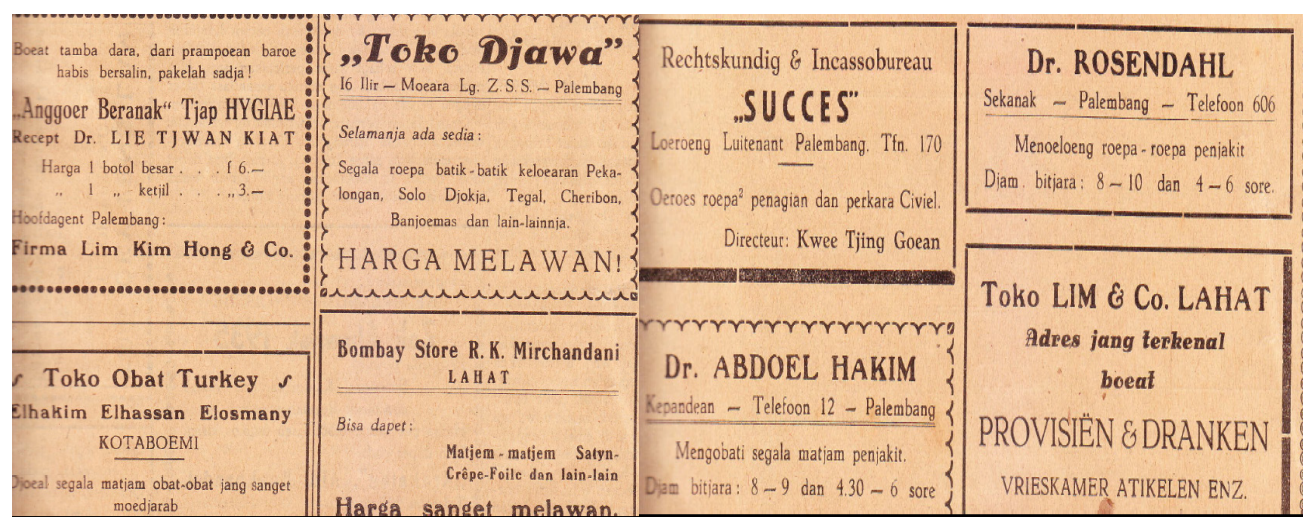

Gambar 5. Iklan yang menggambarkan masyrakat yang multi-etnis 
Keragaman etnis dan latar belakang budaya yang tercermin dalamiklan ini sesungguhnya merupakan ciri penting masyarakat kosmopolitan terutama dalam konteks kolonial dan poskolonial, terlepas dari lokasi geografis tenpat masyarakat itu berada.

Selain itu, yang menarik dari iklan-iklan yang termuat dalam Penghiboer adalah secara berulang-ulang Penerbit Krakatau sendiri diiklankan sebagai penerbit dan percetakan modern yang menjalankan usahanya secara efisien karena menggunakan peralatan yang modern yang diimpor dari Eropa. Dalam satu edisi Penghiboer Nomor 1 Januari 1935 saja ada enam iklan yang mempromosikan kegiatan Krakatau sebagai penyedia layanan percetakan, penyalur buku, dan penjual alat tulis dan kantor. Dari hal tersebut tampaknya seakan-akan Krakatau memanfaatkan posisinya dalam majalah tersebut. Namun, terlihat dari sedemikian beragamnya jenis iklan yang muncul bukan saja menunjukkan betapa beragamnya segmen pasar Penghiboer melainkan juga adanya semangat kosmopolitan redaksinya yang tidak mendiskriminasi pihak yang hendak memasang iklannya dalam majalah tersebut. Sedemikian terbukanya majalah ini sehingga ada iklan yang mengajak pembaca untuk mendukung "Katholiek Kolonisatie Poelo Laoet dengan membeli iapoenja Kalender-boelanan."

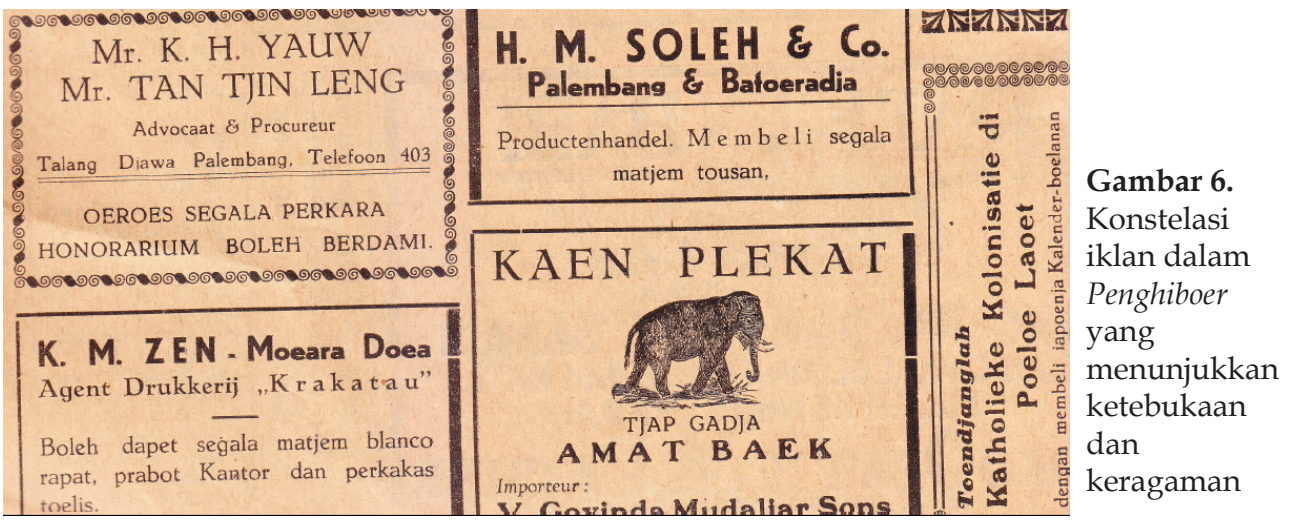

Dengan demikian, betapapun Penghiboer banyak mengandung tulisan yang mengkritik kolonialisme dan cenderung bersifat sekuler tanpa menunjukkan adanya kecenderungan untuk menunjukkan dominasiagama tertentu, tidak pula dihalanginya pihak yang hendak mempromosikan kolonisasi Pulo Laut dalam rangka syiar agama Katolik. Hal ini sangat signifikan terutama jika melihat bahwa iklan kegiatan Katolik ini dimuat dalam majalah yang masyarakat pasarnya mayoritas Muslim dengan redaksi dan pimpinan perusahaan yang diduga Kong $\mathrm{Hu} \mathrm{Cu}$ atau Buda dalam negara yang cenderung mendukung penyebaran agama Kristen Protestan.

\section{PENUTUP}

Majalah Penghiboer yang terbit pertama kali 1 Januari 1935 terbit di Palembang, secara umum menjadi representasi sekaligus indikator bahwa dalam masyarakat kota di Hindia Belanda, terutama di Palembang terdapat wawasan dan kehidupan yang kosmopolitan. Bukan saja tulisan-tulisan yang dimuat di dalamnya, baik itu berupa karya fiksi dan puisi, artikel non-fiksi, maupun iklan sekalipun, menunjukkan adanya komunikasi dan interaksi antara anggota masyarakat berbagai kota di Hindia Belanda, seperti Batavia, Surabaya, dan Palembang melainkan juga dengan kehidupan kosmoplitan di seluruh dunia baik itu di Asia, Eropa, maupun Amerika. Dengan adanya 
gambaran seperti ini, selayaknya kita memikirkan ulang cara kita memahami sejarah Indonesia, khususnya sejarah kesusastraan Indonesia, yang cenderung memandang masyarakat kolonial Hindia Belanda dalam dikotomi sempit Indonesia-Belanda. Selain itu pula, majalah Penghiboer ini yang terus terbit hingga tahun akhir tahun 1940, setidaknya dari dokumen yang saya peroleh, menjadi bukti adanya kegiatan kepenulisan sastra dan industri penerbitan yang hidup subur di luar Batavia dan di luar Jawa sehingga sejarah kesusastraan Indonesia yang selama ini bersifat Bataviasentris atau setidaknya Jawa-sentris juga harus ditinjau ulang agar generasi selanjutnya dapat memahami sejarah bangsanya dengan perspektif yang lebih bijaksana.

\section{DAFTAR PUSTAKA}

Adam, Ahmat B. 1995. The Vernacular Press and the Emergence of Modern Indonesia Consciousness (1855-1913). Ithaca, N.Y.: SEAP.

Adipurwawidjana, Ari J. 2017. "Menuliskan Identitas Hibrid dalam Masyarakat (Pos-)Kolonial." Etnisitas dan Multikulturalisme, Ed. Indra Sarathan. Medan" Obelia. Hlm. 1-23.

Anderson, Benedict. 1991. Imagined Communities: Reflections of the Origin and Spread of Nationalism. London: Verso.

Bhambra, Gurminder K. 2011. "Cosmopolitanism and Postcolonial Critique." The Ashgate Research Companion to Cosmopolitanism. Ed. Maria Rovisco dan

Magdalena Nowicka. Surrey: Ashgate. Hlm. 313-328

Brannigan, John. 1998. New Historicism and Cultural Materialism. London: Macmillan.

Chandra, Elizabeth. 2011. "Fantasizing Chinese/Indonesia Hero: Njoo Cheong

Seng and teh Gagaklodra Series." Archipel, No. 82, hlm. 83-113.

Chandra, Elizabeth. 2016. "The Chinese Holmes: Translating Detective Fiction in Colonial Indonesia." Keio Communication Review, No. 38, hlm. 39-63.

Fischer, Steven R. 1997. Rongorongo: The Easter Island Script: History, Traditions, Texts. Oxford: Clarendon Press.

Jedamski, Doris. 2009. “The Vanishing Act of Sherlock Holmes in Indonesia's National Awakening." Chewing Over the West: Occidental Narratives in NonWestern Readings. Amsterdam: Rodopi. Hlm. 349-379

Kartini, Raden Adjeng. 1921. Letters of a Javanese Princess. Trans. Agnes Louise Symmers. London: Duckworth and Co.

Koninklijke Bibliotheek. "Astra." https://www.kb.nl/themas/tijdschriften/astra. Diakses 14 Juli 2018.

Moriyama, Mikihiro. 2005. Sundanese Print Culture and Modernity in Nineteenth Century West Java. Singapore: Singapore University Press.

NederveenPietrese, Janand BikhuParekh.1995. “ShiftingImaginaries:Decolonization, Internal Decolonization, and Postcoloniality." The Decolonization of Imagination. (ed.) Jan Nederveen Pieterse \& Bikhu Parekh. London: Zed.

Salmon, Claudine. 2010. Sastra Indoneia Awal: Kontribusi Orang Tionghoa. Jakarta: Kepustakaan Populer Gramedia.

Sudibyo, Agus. 2001. Politik Media dan Pertarungan Wacana. Yohyakarta: LkiS.

Woolff, Werner. 1949. "Three Mysteries of Easter Island." The Scientific American, Vol. 180, No. 2, hlm. 50-55. 